\title{
Factors Affecting Methanogenesis and Associated Anaerobic Processes in the Sediments of a Stratified Eutrophic Lake
}

\author{
By J. GWYNFR YN JONES, * BERNARD M. SIMON AND \\ STEVEN GARDENER \\ Freshwater Biological Association, The Ferry House, Ambleside, Cumbria LA22 OLP, U.K.
}

(Received 5 February 1981; revised 11 May 1981)

\begin{abstract}
Factors affecting methanogenesis in the sediments of a eutrophic lake were studied during late summer, a period during which $\mathrm{CH}_{4}$ gas production slowed down dramatically or stopped completely. The most active methanogenesis occurred in the surface sediments and the temperature optimum for the process in these deeper sediments was $30^{\circ} \mathrm{C}$. Addition of $\mathrm{H}_{2}$ or formic acid to sediment slurries stimulated $\mathrm{CH}_{4}$ production to a greater extent than did acetic or pyruvic acid. Analysis of the kinetics of the conversion of $\mathrm{H}_{2}$ to $\mathrm{CH}_{4}$ suggested that the sediments were severely limited in $\mathrm{H}_{2}$, the concentration being considerably less than $2.5 \mu \mathrm{mol}^{-1}$, the $K_{\mathrm{m}}$ for the process. Methanogenesis was not stimulated by the addition of trace quantities of $\mathrm{Ni}^{2+}, \mathrm{Co}^{2+}, \mathrm{MoO}_{4}^{2-}$ or $\mathrm{Fe}^{2+}$ ions but was inhibited by $0.5 \mathrm{mmol} \mathrm{SO}{ }_{4}^{2-} \mathrm{I}^{-1}$. Under natural conditions the sediments were also limited in $\mathrm{SO}_{4}^{2-}$ and sulphate reducers acted as net $\mathrm{H}_{2}$ donors to the methanogens; addition of $\mathrm{SO}_{4}^{2-}$ allowed the sulphate reducers to compete effectively for $\mathrm{H}_{2}$. The addition of $20 \mathrm{mmol} \mathrm{Na}{ }_{2} \mathrm{MoO}_{4} \mathrm{I}^{-1}$ to sediments inhibited methanogenesis but this was not due entirely to its effect in the $\mathrm{H}_{2}$ transfer from sulphate reducers; it also inhibited $\mathrm{CO}_{2}$ uptake by sediments and the production of $\mathrm{CH}_{4}$ from $\mathrm{CH}_{3} \mathrm{COOH}$ and $\mathrm{CO}_{2}$ by cultures of methanogens. It is therefore inadvisable to use $\mathrm{MoO}_{4}^{2-}$ at this concentration as a specific inhibitor of sulphate reducers in such freshwater sediments. Experiments with other inhibitors of methanogens suggested that they may interact with sulphate reducers, acetogens or anaerobic bacteria involved in fatty acid decomposition. Small, sealed sediment cores, which were used to reproduce natural conditions, particularly of available $\mathrm{H}_{2}$ concentration, were injected with trace quantities of $\mathrm{H}^{14} \mathrm{CO}_{3}^{-}$and ${ }^{14} \mathrm{CH}_{3} \mathrm{COOH}$. The results suggested that more than $75 \%$ of the $\mathrm{CH}_{4}$ was derived from $\mathrm{CO}_{2}$ and the remainder from $\mathrm{CH}_{3} \mathrm{COOH}$. The overall rates of methanogenesis in the small cores agreed well with results from the field.
\end{abstract}

\section{INTRODUCTION}

Whereas, in the past, decomposition processes in lakes have been considered largely in terms of aerobic respiration and the oxygen consumption of the sediment (Hargrave, 1969; Wetzel et al., 1972; Jones, 1976), more recent attention has focused on anaerobic processes. $\mathrm{SO}_{4}^{2-}$ reduction is an important component of carbon turnover in marine sediments (Fenchel \& Blackburn, 1979; Jørgensen, 1980) but it plays a less significant role in fresh water (Jones \& Simon, 1980, 1981), where denitrification and methanogenesis are quantitatively more important. In certain North American lakes more than half the total carbon input to the sediment may be converted to $\mathrm{CH}_{4}$ (Rudd \& Hamilton, 1978; Fallon et al., 1980) but this pathway is quantitatively less important in temperate lakes of the English Lake District (Jones \& Simon, 1980). The interaction of methanogens with other anaerobes (particularly sulphate reducers) in freshwater sediments was first studied experimentally by Cappenberg $(1974 a, b)$ and Cappenberg \& Prins (1974) who concluded that sulphate reducers converted 
lactate to acetate which, in turn, was used by the methanogens. They calculated that most (70\%) of the $\mathrm{CH}_{4}$ generated in freshwater sediments was derived from acetate and that accumulation of sulphide inhibited methanogenesis. The demonstration by Bryant et al. (1977) that, in the absence of $\mathrm{SO}_{4}^{2-}$, Desulfovibrio could act as a net $\mathrm{H}_{2}$ donor to methanogens provided a possible alternative explanation for events in $\mathrm{SO}_{4}^{2-}$-limited freshwater sediments. The addition of $\mathrm{SO}_{4}^{2-}$ to such sediments inhibits methanogenesis (Winfrey \& Zeikus, 1977) and under these circumstances it is possible to demonstrate competition between the anaerobic bacteria for $\mathrm{H}_{2}$ and acetate. This is in marked contrast to the marine system where, in the presence of excess $\mathrm{SO}_{4}^{2-}$, the sulphate reducers compete successfully with methanogens for $\mathrm{H}_{2}$ (Abram \& Nedwell, 1978).

Some investigations of the relative importance of acetate and $\mathrm{H}_{2} / \mathrm{CO}_{2}$ as precursors of $\mathrm{CH}_{4}$ in freshwater sediments have been conducted on sediment slurries incubated under artificial atmospheres (Cappenberg \& Prins, 1974; Winfrey \& Zeikus, 1979) but evidence of limitation of methanogenesis by $\mathrm{H}_{2}$ has been reported (Winfrey et al., 1977; Strayer \& Tiedje, 1978). Therefore experimental procedures which alter the natural concentration of $\mathrm{H}_{2}$ (an extremely insoluble substrate) could introduce errors in estimates of the importance of the $\mathrm{H}_{2} / \mathrm{CO}_{2}$ pathway. However, results are being obtained which suggest that a greater proportion of $\mathrm{CH}_{4}$ is produced by this pathway (Winfrey \& Zeikus, 1979; Zaiss, 1981) than originally suggested by Cappenberg \& Prins (1974).

Recent studies with gas traps in Cumbrian lakes (Jones \& Simon, 1980, 1981; Jones et al., 1980) have shown that the $\mathrm{CH}_{4}$ release rate was low compared with the more eutrophic American waters. In addition, gas release often decreased dramatically or stopped completely in late summer, before the lakes overturned. Methanogens (Zeikus \& Winfrey, 1976; Zaiss \& Kaltwasser, 1979), like sulphate reducers (Abdollahi \& Nedwell, 1979), are temperature limited in such environments, but in a stratified lake the temperature in the profundal zone is relatively constant $\left(6^{\circ} \mathrm{C}\right.$ to $\left.8^{\circ} \mathrm{C}\right)$ at this time of year. The purpose of this investigation was threefold: to determine what limited methanogenesis in late summer, to use selective inhibitors to investigate the interactions of methanogens with sulphate reducers and other anaerobes, and to determine the relative importance of $\mathrm{CO}_{2}$ and acetate as precursors of $\mathrm{CH}_{4}$ in such a way that the natural $\mathrm{H}_{2}$ concentration was not altered.

\section{METHODS}

Sampling. Sediment and water samples were taken from the profundal zone and the hypolimnion of Blelham Tarn in the English Lake District during summer stratification, 1980. The site is described in more detail by Jones \& Simon $(1980,1981)$. Sediment samples were taken with a Jenkin surface-mud sampler and the sealed cores were returned to the laboratory and sampled within $2 \mathrm{~h}$. Water samples were taken with a peristaltic pump sampler at fixed distances from the sediment-water interface determined by an opto-electronic detector (Cunningham \& Davison, 1980). Water samples to be analysed for gas content were taken directly into ground glass-stoppered bottles which were flushed with at least three times their own volume of water. The gas traps and sampling procedure were those described by Jones \& Simon (1980).

Physical and chemical analyses. Dissolved $\mathrm{CO}_{2}$ and $\mathrm{CH}_{4}$ in the water and sediment and the contents of the gas traps were analysed by the methods described by Jones \& Simon (1980). $\mathrm{SO}_{4}^{2-}$ was determined according to Tabatabai (1974) and $\mathrm{S}^{2-}$ according to Rees et al. (1971). Dissolved $\mathrm{O}_{2}$ and temperature were measured in the field with a combination oxygen meter and thermistor (Model 57, Yellow Springs Instruments Co., Yellow Springs, Ohio, U.S.A.). Low molecular weight fatty acids $\left(\mathrm{C}_{1}\right.$ to $\left.\mathrm{C}_{4}\right)$ were determined gas chromatographically by direct, on-column injection of $2 \mu \mathrm{l}$ of untreated aqueous samples into a Perkin Elmer F30 gas chromatograph connected to an LDC 308 computing integrator. The $2 \mathrm{~m}$ ( $1.75 \mathrm{~mm}$ i.d.) glass column was packed with $5 \% \mathrm{H}_{3} \mathrm{PO}_{4}$ and $15 \%$ Free Fatty Acid Phase on 60/80 mesh Chromosorb W.AW (Phase Separations Ltd, Queensferry, U.K.). The oven was isothermal at $150^{\circ} \mathrm{C}$ and the injector and flame ionization detector temperature was $200^{\circ} \mathrm{C}$. The carrier gas was $\mathrm{N}_{2}\left(40 \mathrm{ml} \mathrm{min} \mathrm{mi}^{-1}, 552 \mathrm{kPa}\right)$ and was mixed with $\mathrm{H}_{2}(117 \mathrm{kPa})$ and air $(138 \mathrm{kPa})$ at the detector. Although day-to-day performance of the column varied, the detection limit for individual fatty acids was never higher than 5 to $10 \mu \mathrm{mol} \mathrm{^{-1 }}$.

Sample preparation. Wherever possible, samples were handled according to Hungate procedures to maintain strictly anaerobic conditions. The use of serum bottles and the purification of gases followed the general methods 
described by Latham \& Wolin (1978). Subsamples of sediment were taken as follows: (a) by extrusion of the sediment core using the device described by Jones (1976) except that the head of the core was enclosed in oxygen-free gas $\left(\mathrm{N}_{2} / \mathrm{CO}_{2}, 95: 5, \mathrm{v} / \mathrm{v}\right)$; (b) by slow suction of surface sediment and overlying water into a Buchner flask which had been previously evacuated and filled several times with $\mathrm{N}_{2} / \mathrm{CO}_{2}$; (c) by insertion of small cores (Jones \& Simon, 1981) which were stoppered under water and removed. The slurry samples collected according to (a) and (b) were dispensed into serum bottles. The small cores which did not contain a gas phase were used in an attempt to determine rates of methanogenesis under conditions as close as possible to those which occur in the field.

Experiments in serum bottles. Samples of sediment slurry (usually $5 \mathrm{ml}$ ) were dispensed into $30 \mathrm{ml}$ serum bottles. Substrates, mineral nutrients and inhibitors were added as $\times 100$ strength aqueous solutions to give the final concentrations described in the text. The bottles were incubated in a shaking water bath. Modification of the gas phase was achieved by injection of a known quantity of gas through the butyl rubber septum or, if complete replacement was required, by flushing before the septum was sealed in place.

Experiments in small cores. In an attempt to maintain natural conditions, and to prevent loss of $\mathrm{H}_{2}$ from surface sediment samples, rates of conversion of $\mathrm{H}^{14} \mathrm{CO}_{3}^{-}$and ${ }^{14} \mathrm{CH}_{3} \mathrm{COOH}$ to ${ }^{14} \mathrm{CH}_{4}$ were determined in sealed small cores, by a method analogous to that of Jørgensen (1978) for $\mathrm{SO}_{4}^{2-}$ reduction. No additions of gas were made to these cores and it was assumed that the concentration of $\mathrm{H}_{2}$ was unaltered by this handling procedure. Cores were inoculated at $1 \mathrm{~cm}$ intervals with either $20 \mu{ }^{14} \mathrm{CH}_{3} \mathrm{COOH}$ solution (equivalent to $0.25 \mu \mathrm{Ci}$, specific activity

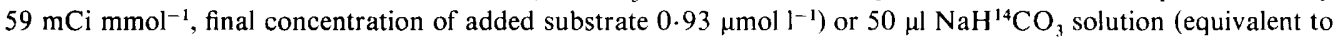

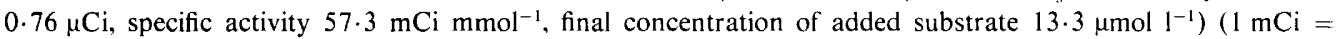
$37 \mathrm{MBq}$ ). These additions of ${ }^{14} \mathrm{CH}_{3} \mathrm{COOH}$ and $\mathrm{NaH}^{14} \mathrm{CO}_{3}$ were equivalent to approximately $2.5 \%$ and $0.4 \%$, respectively, of the natural concentrations of these methanogenic substrates. They could therefore be treated as trace additions, and the calculation of the turnover rate was identical to that used by Jørgensen (1978) for $\mathrm{SO}_{4}^{2-}$ reduction. When required, solutions of $\mathrm{Na}_{2} \mathrm{MoO}_{4}(45 \mu \mathrm{l})$ and $\mathrm{K}_{2} \mathrm{SO}_{4}(10 \mu \mathrm{l})$ were added with the radioactive substrates giving final concentrations of $20 \mathrm{mmol} \mathrm{l}^{-1}$ and $0.5 \mathrm{mmol}^{-1}$ respectively. The small cores were incubated for $24 \mathrm{~h}$ at $10^{\circ} \mathrm{C}$ and then frozen at $-20^{\circ} \mathrm{C}$. The frozen sediment cores were extruded and sawn into segments at depth intervals of $1 \mathrm{~cm}$. The ${ }^{14} \mathrm{CH}_{4}$ and ${ }^{14} \mathrm{CO}_{2}$ were then recovered by a method based on that of Zehnder et al. (1979). The frozen sediment segments were placed in $30 \mathrm{ml}$ Teflon open top septum vials (Tuf Tainers, Pierce \& Warriner Ltd, Chester, U.K.) and $0.5 \mathrm{ml} 10 \mathrm{M}-\mathrm{NaOH}$ was added to retain ${ }^{14} \mathrm{CO}_{2}$ and ${ }^{14} \mathrm{CH}_{3} \mathrm{COOH}$ in solution. The sediment was thawed and a subsample of the headspace containing ${ }^{14} \mathrm{CH}_{4}$ was injected into a scintillation vial which contained $20 \mathrm{ml}$ of the toluene-based fluor. The recovery with this procedure was consistently about $76 \%$ and results were corrected for this. The total ${ }^{14} \mathrm{CH}_{4}$ content of the septum vial was calculated from Henry's law and published values of the constant $K$. To determine ${ }^{14} \mathrm{CO}_{2}, 2 \mathrm{ml}$ of $1 \cdot 5 \mathrm{M}-\mathrm{H}_{2} \mathrm{SO}_{4}$ was then added to the sediment to which ${ }^{14} \mathrm{CH}_{3} \mathrm{COOH}$ had been added and further subsamples of head space, now also containing ${ }^{14} \mathrm{CO}_{2}$, were injected into a serum bottle containing $0.25 \mathrm{ml}$ phenethylamine, and left overnight. Excess ${ }^{14} \mathrm{CH}_{4}$ was flushed out for $1 \mathrm{~min}$ with $\mathrm{N}_{2}$, and the phenethylamine was incorporated in $10 \mathrm{ml}$ of a fluor containing $100 \mathrm{~g}$ naphthalene, $4 \mathrm{~g}$ PPO and $0.05 \mathrm{~g}$ POPOP in 11 1,4-dioxan, to which a further $100 \mathrm{ml}$ of phenethylamine was added. The total ${ }^{14} \mathrm{CO}_{2}$ content in the septum vial was calculated from Henry's law as described above. The efficiency of all separation and absorption procedures was checked with known quantities of $\mathrm{CH}_{4},{ }^{14} \mathrm{CO}_{2}$ and ${ }^{14} \mathrm{CH}_{3} \mathrm{COOH}$. The radioactivity in the samples was then measured in a Tracor Analytic Mark III liquid scintillation counter (Nuclear Chicago Ltd). Samples were corrected for quench with a ${ }^{133}$ Ba external standard, by plotting the inverse of the relative pulse height against efficiency. This procedure gives better linearity than the channels ratio method.

Enumeration of anaerobic bacteria. Numbers of sulphate reducers were determined by a most probable number (MPN) procedure (Jones \& Simon, 1981) using the medium of Postgate (1963) except that acetate- as well as lactate-utilizing bacteria were counted. Tubes in which a black precipitate of FeS developed were scored as positive. The MPN of acetate-utilizing and $\mathrm{H}_{2} / \mathrm{CO}_{2}$-utilizing methanogens was determined in serum bottles using the liquid medium described below. Precautions to maintain strictly anaerobic conditions were observed during all stages of dilution and inoculation. Production of $\mathrm{CH}_{4}$ in the bottles was determined gas chromatographically. The MPN tubes for sulphate reducers were incubated at $30^{\circ} \mathrm{C}$ for $34 \mathrm{~d}$ and the serum bottles were checked for the production of $\mathrm{CH}_{4}$ after 12,19 and $26 \mathrm{~d}$ incubation at $30^{\circ} \mathrm{C}$. The contents of the most dilute positive tubes were used to culture methanogens for inhibitor studies.

Culture media for methanogens. The medium was essentially that of Patel et al. (1978). The final concentrations of $\mathrm{CoCl}_{2} \cdot 6 \mathrm{H}_{2} \mathrm{O}, \mathrm{NiCl}_{2}, \mathrm{Na}_{2} \mathrm{MoO}_{4} \cdot 2 \mathrm{H}_{2} \mathrm{O}$ (each $\left.1 \mathrm{mg} \mathrm{l}^{-1}\right)$ and $\mathrm{FeSO}_{4}\left(150 \mathrm{mg} \mathrm{l}^{-1}\right)$ were high enough to ensure adequate supplies of these micronutrients (Schonheit et al. 1979) as well as $\mathrm{Fe}^{2+}$ and $\mathrm{SO}_{4}^{2-}$ (Patel et al., 1978; Hoban \& van den Berg, 1979). Acetate-utilizing methanogens were grown in a medium containing $2.5 \mathrm{mg}$ $\mathrm{CH}_{3} \mathrm{COONa} .3 \mathrm{H}_{2} \mathrm{O}^{-1}$ under an atmosphere of $\mathrm{N}_{2} / \mathrm{CO}_{2}(95: 5)$. The medium for hydrogen-utilizing methanogens contained no acetate and the gas phase was $\mathrm{H}_{2} / \mathrm{CO}_{2}(95: 5)$. Primary enrichments of the two types of methanogens were obtained in liquid medium and then subcultured on to the same medium solidified with $1.5 \%$ agar and allowed to set as a slope in $50 \mathrm{ml}$ serum bottles. Individual colonies were then returned to liquid medium. 
and this process was repeated twice further before the cultures were assumed to be pure and used for experimental purposes. The cultures were checked for purity under phase-contrast illumination and for the presence of coenzyme $\mathrm{F}_{420}$ under ultraviolet epifluorescence microscopy.

Analysis of data. Where possible, $95 \%$ confidence limits of variables have been calculated, but when there were insufficient data to provide information on the parent distribution of any given variable, the results are presented as means with standard deviations.

\section{RESULTS AND DISCUSSION}

The field data obtained in 1980 are summarized in Fig. 1; the concentrations of dissolved gases were those found in water samples taken from $0.25 \mathrm{~m}$ above the mud. A rapid decrease in dissolved $\mathrm{O}_{2}$ was observed during May and concentrations of dissolved $\mathrm{CH}_{4}$ and $\mathrm{CO}_{2}$ increased throughout the summer. The slight increase in the rate of dissolved $\mathrm{CH}_{4}$ accumulation in August coincided with a decrease in $\mathrm{CO}_{2}$ concentration, and immediately preceded a large increase in the rate of $\mathrm{CH}_{4}$ bubble release from the sediment (Fig. 1a). The rate of release was low in 1980 , probably reflecting the poor summer (monthly rainfall values are provided in Fig. 1), and therefore the decrease which occurred at the end of August was less marked than in previous seasons. Much of the experimental work on factors affecting methanogenesis was performed during this period. The build-up of dissolved $\mathrm{CH}_{4}$ in the water column was parallel with that which occurred in the sediment (Fig. 2). There was no evidence of significant methanogenesis in the water column. Although the highest $\mathrm{CH}_{4}$ concentrations were found at depths of $10 \mathrm{~cm}$ in the sediments, the surface sediment samples were more actively methanogenic than those taken from below the surface after anoxic conditions had developed in the hypolimnion (Table 1). The optimum temperature for methanogenesis was $30^{\circ} \mathrm{C}$, which was slightly lower than that found for Lake Mendota sediments (Zeikus \& Winfrey, 1976). The energy of activation was $130 \mathrm{~kJ} \mathrm{~mol}^{-1}, 50 \%$ higher than that reported for $\mathrm{SO}_{4}^{2-}$ reduction in saltmarsh sediment (Abdollahi \& Nedwell, 1979), and was the same for surface sediment as for that taken from a depth of $8 \mathrm{~cm}$. One might speculate that the possession of identical temperature characteristics suggests that the populations at these depths were of the same origin, and that the one which developed in the surface layer during the summer originated at greater depths. The rate of methanogenesis, as measured in serum bottles, appeared to be cold sensitive, decreasing very rapidly below $15^{\circ} \mathrm{C}$. Whether this was true cold sensitivity (Morris, 1974) or merely reflected an inadequacy of the experimental procedure, was uncertain.

Addition of $\mathrm{H}_{2}$ (as a $\mathrm{H}_{2} / \mathrm{CO}_{2}$ mixture) to serum bottles caused an immediate stimulation of $\mathrm{CH}_{4}$ production in slurries of surface and deeper sediments (Table 1) which was greater than that caused by equivalent quantities of acetate and pyruvate, and comparable with that obtained with formate. Rapid utilization of formate as a $\mathrm{H}_{2}$ donor has been reported in other freshwater sediments (Strayer \& Tiedje, 1978; Winfrey et al., 1977). Stimulation by $\mathrm{H}_{2}$ was always observed and ranged between $35 \%$ and $750 \%$, but addition of acetate to sediment samples taken during the period July to November (1980) did not produce such consistent stimulation when acetate was added. On occasions, particularly during September, slight inhibition was observed, but this could not be explained in terms of seasonal changes in substrate concentrations. The concentration of acetate in the sediment interstitial water during this period varied between 20 and $70 \mu \mathrm{mol} \mathrm{l}^{-1}$, which was similar to that reported by Strayer \& Tiedje (1978) but almost an order of magnitude less than that found in the hypereutrophic Wintergreen Lake (Molongoski \& Klug, 1980). Results of further investigations into the effect of $\mathrm{H}_{2}$ concentration on the rate of methanogenesis showed that the process conformed to Michaelis-Menten kinetics (Fig. $3 a$ ) with a $V_{\max }$ of $94 \mu \mathrm{mol} \mathrm{CH}_{4}$ $\mathrm{g}^{-1} \mathrm{~d}^{-1}$ and a $K_{\mathrm{m}}$ of $2.5 \mu \mathrm{mol} \mathrm{1^{-1 }}$. Gas chromatographic analysis of the sediments failed to detect $\mathrm{H}_{2}$ although the limit of detection for the method used was about $0.1 \mu \mathrm{mol} \mathrm{l}^{-1}$. The $K_{\mathrm{m}}$ value was similar to that obtained by Strayer \& Tiedje (1978), and the failure to detect free 


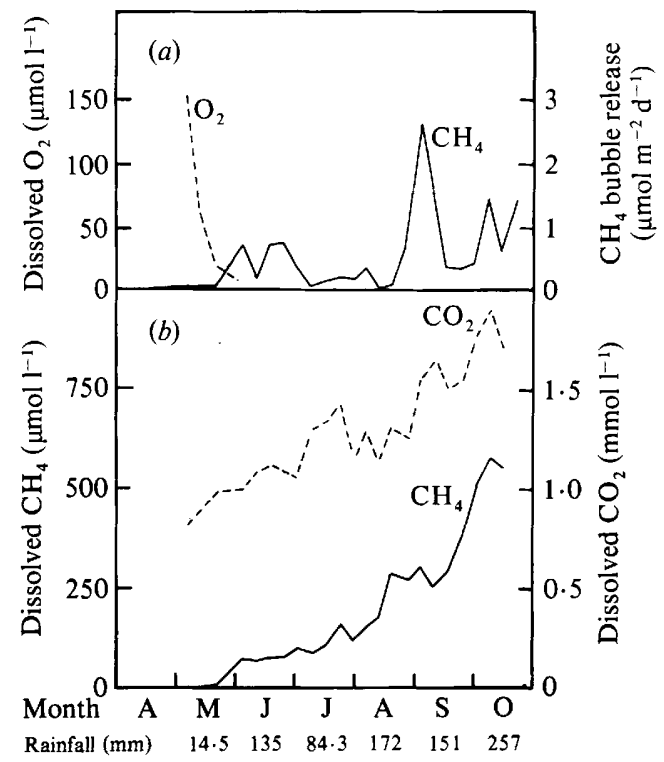

Fig. 1. Seasonal changes in the concentration of gases in the profundal water of Blelham Tarn during summer stratification, 1980. Monthly rainfall figures are also shown. (a) Dissolved $\mathrm{O}_{2}$ concentration $0.25 \mathrm{~m}$ above the sediment (----), and methane bubble release from the sediment into gas traps ( $\left(\right.$ ). (b) Dissolved $\mathrm{CO}_{2}(---)$ and $\mathrm{CH}_{4}(\stackrel{-}{-}$ concentrations $0.25 \mathrm{~m}$ above the sediment.

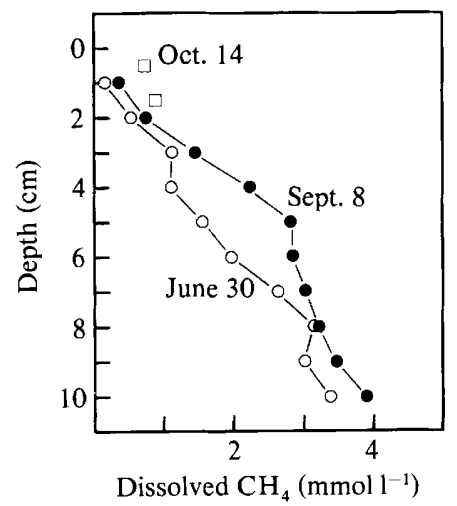

Fig. 2. Depth distribution of dissolved $\mathrm{CH}_{4}$ in profundal sediments of Blelham Tarn on June $30(\mathrm{O})$, September $8(\bigcirc)$ and October $14(\square) 1980$.

$\mathrm{H}_{2}$ indicated that the sediment methanogens were limited by $\mathrm{H}_{2}$ at this time of year. Addition of large quantities of $\mathrm{H}_{2}$ (as a $\mathrm{H}_{2} / \mathrm{CO}_{2}, 95: 5$ mixture) to the sample could result in depletion of the $\mathrm{CO}_{2}$ present (Fig. $3 b$ ) and therefore incubation times for such experiments were kept short.

The requirements of certain methanogens for Ni, Co and Mo ions (Schonheit et al., 1979) and for optimum levels of $\mathrm{Fe}^{2+}$ for growth (Patel et al., 1978) have been demonstrated in pure cultures, but no stimulation of methanogenesis was observed on addition of these ions at final concentrations of $1.0 \mu \mathrm{mol} \mathrm{l}{ }^{-1}\left(\mathrm{Ni}^{2+}, \mathrm{Co}^{2+}, \mathrm{MoO}_{4}^{2-}\right)$ and $500 \mu \mathrm{mol} \mathrm{l} \mathrm{I}^{-1}\left(\mathrm{Fe}^{2+}\right)$ to sediment slurries sampled in late summer. Some stimulation occurred when $\mathrm{Ni}$, Co and Mo were added to surface sediments in early July, but not with sediments from $8 \mathrm{~cm}$ depth. One 
Table 1. Effect of $\mathrm{H}_{2}$ concentration and carbon sources on methanogenesis in samples of sediment taken from different depths

Sample slurries were incubated in serum bottles at $30^{\circ} \mathrm{C}$ for $22 \mathrm{~h}$. The coefficient of variation on determinations made in triplicate was usually $5 \%$.

\begin{tabular}{|c|c|c|c|}
\hline & & $\begin{array}{l}\text { methano } \\
\text { g dry wt) }\end{array}$ & \\
\hline & & ole depth & \\
\hline Conditions & $0-1$ & $2 \cdot 5-3 \cdot 5$ & $7 \cdot 5-8 \cdot 5$ \\
\hline & $29 \cdot 2$ & $21 \cdot 3$ & $5 \cdot 5$ \\
\hline & $39 \cdot 5$ & $29 \cdot 4$ & 8.4 \\
\hline & $67 \cdot 1$ & $47 \cdot 0$ & $13 \cdot 1$ \\
\hline ed & $213 \cdot 2$ & $182 \cdot 1$ & $115 \cdot 7$ \\
\hline $\left.0 \mu \mathrm{mol} \mathrm{l}^{-1}\right)$ & $37 \cdot 3$ & 29.4 & 9.5 \\
\hline$\left(400 \mu \mathrm{mol} \mathrm{l}^{-1}\right)$ & $78 \cdot 4$ & $66 \cdot 8$ & $17 \cdot 6$ \\
\hline$\left(400 \mu \mathrm{mol} \mathrm{I} \mathrm{I}^{-1}\right)$ & $36 \cdot 2$ & $33 \cdot 4$ & $9 \cdot 2$ \\
\hline
\end{tabular}

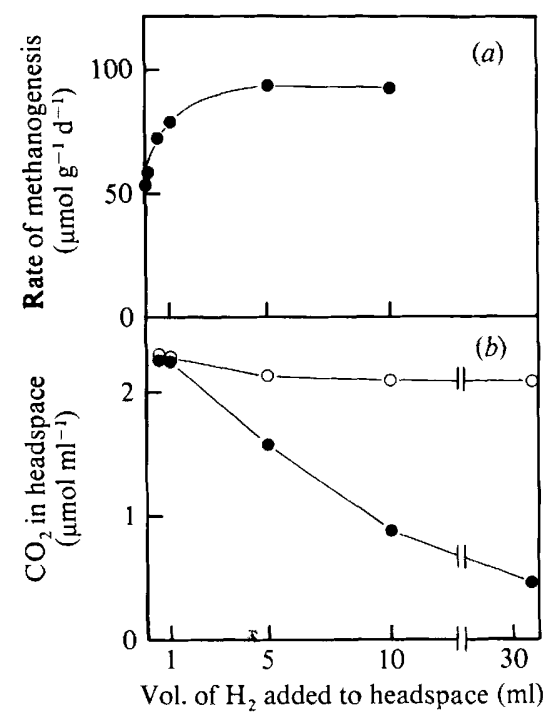

Fig. 3. Effect of the partial pressure of $\mathrm{H}_{2}$ on (a) methanogenesis and (b) the final concentration of $\mathrm{CO}_{2}$ in the headspace of the serum bottle after incubation of sediment slurries at $30^{\circ} \mathrm{C}$ for $21 \mathrm{~h}(\mathrm{O})$ and $45 \mathrm{~h}(\mathrm{O})$.

interpretation of these observations might be that the minor nutrients were more readily available at low $E_{\mathrm{h}}$ values. Ferrous ions did not stimulate methanogenesis but concentrations of $\mathrm{Fe}^{2+}$ are naturally high in anoxic profundal sediments (Jones, 1982). Addition of $500 \mu \mathrm{mol}$ $\mathrm{SO}_{4}^{2-} 1^{-1}$ to the sediment slurries caused an immediate inhibition of methanogenesis, a result consistent with other findings from $\mathrm{SO}_{4}^{2-}$-limited sediments (Winfrey \& Zeikus, 1977; Zaiss, 1981; Zeikus, 1977). In late summer the concentration of $\mathrm{SO}_{4}^{2-}$ in profundal sediment interstitial water was less than $10 \mu \mathrm{mol} \mathrm{^{-1 }}$. Under such circumstance the sulphate-reducing bacteria are limited by the electron acceptor concentration and become net hydrogen donors to the methanogens. Such an interaction was first described with pure cultures by Bryant $e t$ al. (1977). Addition of $\mathrm{SO}_{4}^{2-}$ allowed the sulphate reducers to compete effectively for $\mathrm{H}_{2}$ once more (Winfrey \& Zeikus, 1977; Abram \& Nedwell, 1978), thus inhibiting methanogenesis. 
Bearing in mind the $\mathrm{H}_{2}$-limited state of the sediment in late summer, we decided to investigate further the interactions of the methanogens with other potential $\mathrm{H}_{2}$-utilizing bacteria. At this time of year, estimates of the populations of methanogens and sulphate reducers in the sediment, as estimated by MPN procedures, were of about the same order of magnitude at $10^{5}(\mathrm{~g} \text { dry wt })^{-1}$. Counts of acetate-utilizing methanogens were about $25 \%$ of the counts of those which utilized $\mathrm{H}_{2}$ and $\mathrm{CO}_{2}$, and lactate-utilizing sulphate reducers were six times more numerous than acetate oxidizers. The activation of $\mathrm{SO}_{4}^{2-}$ by ATP, and therefore the metabolism of sulphate reducers, is inhibited by molybdate (Peck, 1959) and this anion has been used quite extensively at a final concentration of $20 \mathrm{mmol} \mathrm{l}^{-1}$ as a specific inhibitor of sulphate-reducing bacteria in marine sediments (Oremland \& Taylor, 1978). We decided to examine its effectiveness in $\mathrm{SO}_{4}^{2-}$-limited freshwater sediments. Addition of molybdate at $20 \mathrm{mmol}^{-1}$ resulted in an $80 \%$ inhibition of methanogenesis under a $\mathrm{N}_{2} / \mathrm{CO}_{2}$ atmosphere and $60 \%$ inhibition under $\mathrm{H}_{2} / \mathrm{CO}_{2}$. This might be expected in a system where sulphate reducers were acting as $\mathrm{H}_{2}$ donors to the methanogens, but a similar inhibition in the presence of excess $\mathrm{H}_{2}$ was unexpected. Addition of selenate $\left(1 \mathrm{mmol} \mathrm{1}^{-1}\right)$, another inhibitor of sulphate reducers, had the same effect. A further examination of the effect with time showed that the inhibition was more marked, in all cases, if the inhibitor was added at the beginning of the experiment than if the addition was made after a period of incubation during which methanogenesis had started. Under an atmosphere of $\mathrm{N}_{2} / \mathrm{CO}_{2}$ and in the presence of added $\mathrm{SO}_{4}^{2-}$, molybdate stimulated methanogenesis. This was consistent with the interaction between sulphate reducer and methanogen described above, in that the addition of $\mathrm{SO}_{4}^{2-}$ allowed the former to compete for $\mathrm{H}_{2}$ once again. Addition of molybdate would therefore inhibit the competitor and allow the formation of more $\mathrm{CH}_{4}$. In the presence of excess $\mathrm{H}_{2}$, however, molybdate added at zero time inhibited methanogenesis whether excess $\mathrm{SO}_{4}^{2-}$ was added or not. This suggested that at the concentration used, molybdate might affect bacteria other than sulphate reducers. When $\mathrm{H}_{2}$ was in excess, total $\mathrm{CO}_{2}$ consumption, in both the presence and absence of excess $\mathrm{SO}_{4}^{2-}$, was inhibited by molybdate. Analysis of these samples after storage for $7 \mathrm{~d}$ in the refrigerator showed that addition of molybdate had also caused an accumulation of fatty acids, particularly acetic acid. Incubation in the presence of excess $\mathrm{H}_{2}$ stimulated the production of all fatty acids, particularly acetic, the concentration of which was at least an order of magnitude higher than those of the other acids. Lactic acid was not detected. In the presence of excess $\mathrm{H}_{2}$, molybdate inhibited the production of acetic, butyric and valeric acids, but not of propionic acid. The experiment was repeated with inhibitors of both sulphate reducers and methanogens, and the samples were analysed immediately. The results obtained were essentially the same and are summarized in Table 2 . All the inhibitors suppressed methanogenesis, chloroform being the most effective, and caused the accumulation of low molecular weight fatty acids. The presence of excess $\mathrm{H}_{2}$ stimulated methanogenesis as well as fatty acid production. Under an atmosphere of $\mathrm{N}_{2} / \mathrm{CO}_{2}$, molybdate inhibited $\mathrm{H}_{2}$-utilizing organisms and fatty acids accumulated; a similar accumulation of fatty acids occurred in the presence of excess $\mathrm{H}_{2}$. These results might be explained in terms of inter-species hydrogen transfer between anaerobic bacteria which degrade fatty acids and the methanogens and sulphate reducers which act as $\mathrm{H}_{2}$ sinks. The decomposition of the fatty acids becomes thermodynamically feasible only under the low partial pressures of $\mathrm{H}_{2}$ created by the methanogens and sulphate reducers; similar syntrophic associations have been demonstrated in anaerobic digestor sludge (Boone \& Bryant, 1980; Mclnerney et al., 1979). The inhibition of acetate formation at low temperatures by molybdate in the presence of a high partial pressure of $\mathrm{H}_{2}$ is less easily explained, unless the anion affected acetogenic bacteria directly. The accumulation of large quantities of acetic acid at temperatures comparable to those found in the profundal zone suggested that acetogens might be more important in the Blelham Tarn sediments than in those studied by Braun et al. (1979), where viable counts were two orders of magnitude lower than those of the methanogens.

Further evidence of the non-specific nature of molybdate inhibition at this concentration 
J. G. JONES, B. M. SIMON AND S. GARDENER

Table 2. Effect of inhibitors on the production of $\mathrm{CH}_{4}$ and the accumulation of low molecular weight fatty acids in profundal sediment slurries

Samples were incubated at $30^{\circ} \mathrm{C}$ for $24 \mathrm{~h}$.

\begin{tabular}{|c|c|c|c|c|}
\hline \multirow[b]{2}{*}{ Conditions } & \multicolumn{4}{|c|}{ Rate of production $\left[\mu \mathrm{mol}(\mathrm{g} \text { dry } w t)^{-1} \mathrm{~d}^{-1}\right]$} \\
\hline & $\mathrm{CH}_{4}$ & $\begin{array}{l}\text { Acetic } \\
\text { acid }\end{array}$ & $\begin{array}{c}\text { Propionic } \\
\text { acid }\end{array}$ & $\begin{array}{c}\text { Butyric } \\
\text { acid }\end{array}$ \\
\hline $\begin{array}{l}\mathrm{N}_{2} / \mathrm{CO}_{2} \text { atmosphere } \\
\quad \text { Control } \\
\quad+\mathrm{Na}_{2} \mathrm{MoO}_{4}\left(20 \mathrm{mmol} \mathrm{l}^{-1}\right) \\
\quad+\mathrm{Na}_{2} \mathrm{SeO}_{4}\left(1 \mathrm{mmol} \mathrm{l}^{-1}\right) \\
\quad+\mathrm{CHCl}_{3}(0 \cdot 5 \%, \mathrm{v} / \mathrm{v}) \\
+\mathrm{BESA}^{*}\left(100 \mathrm{mg} \mathrm{l}^{-1}\right)\end{array}$ & $\begin{array}{r}31 \cdot 1 \\
13 \cdot 5 \\
14 \cdot 5 \\
0 \cdot 2 \\
9 \cdot 2\end{array}$ & $\begin{array}{r}1 \cdot 2 \\
11 \cdot 3 \\
8 \cdot 7 \\
7 \cdot 0 \\
8 \cdot 0\end{array}$ & $\begin{array}{l}\text { ND } \\
1 \cdot 3 \\
0 \cdot 3 \\
0 \cdot 9 \\
1 \cdot 9\end{array}$ & $\begin{array}{l}\text { ND } \\
0.09 \\
0.05 \\
0.05 \\
0.2\end{array}$ \\
\hline $\begin{array}{l}\mathrm{H}_{2} / \mathrm{CO}_{2} \text { atmosphere } \\
\quad \mathrm{Control} \\
\quad+\mathrm{Na}_{2} \mathrm{MoO}_{4}\left(20 \mathrm{mmol} \mathrm{l}^{-1}\right) \\
\quad+\mathrm{Na}_{2} \mathrm{SeO}_{4}\left(1 \mathrm{mmol} \mathrm{l}^{-1}\right) \\
\quad+\mathrm{CHCl}_{3}(0 \cdot 5 \%, \mathrm{v} / \mathrm{v}) \\
\quad+\mathrm{BESA}^{*}\left(100 \mathrm{mg} \mathrm{l}^{-1}\right)\end{array}$ & $\begin{array}{r}50 \cdot 0 \\
20 \cdot 4 \\
40 \cdot 1 \\
0 \cdot 4 \\
16 \cdot 5\end{array}$ & $\begin{array}{l}5 \cdot 9 \\
4 \cdot 4 \\
2 \cdot 9 \\
5 \cdot 2 \\
7 \cdot 5\end{array}$ & $\begin{array}{l}3 \cdot 6 \\
2 \cdot 2 \\
3 \cdot 4 \\
1 \cdot 9 \\
3 \cdot 6\end{array}$ & $\begin{array}{l}0 \cdot 6 \\
0 \cdot 1 \\
0 \cdot 3 \\
0 \cdot 2 \\
0 \cdot 6\end{array}$ \\
\hline
\end{tabular}

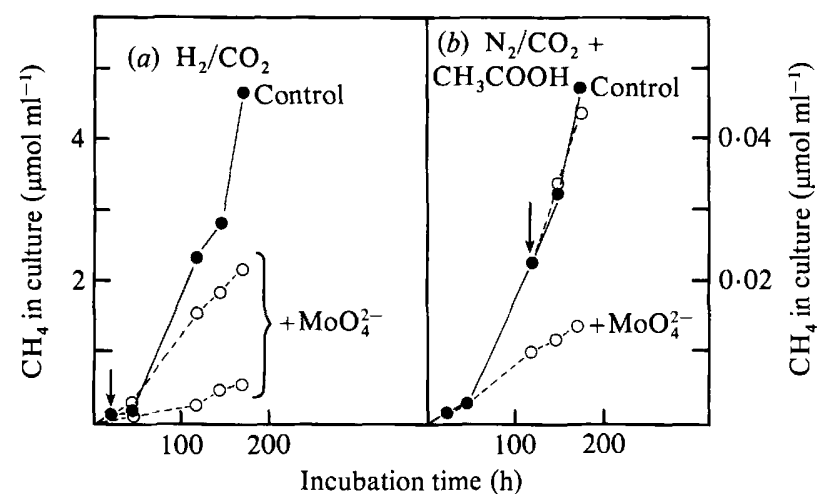

Fig. 4. Effect of molybdate (final concentration $20 \mathrm{mmol}^{-1}$ ) on the production of $\mathrm{CH}_{4}$ by pure cultures of $(a)$ a $\mathrm{H}_{2} / \mathrm{CO}_{2}$-utilizing methanogen, and $(b)$ an acetate-utilizing methanogen. $\mathrm{O}$, Control cultures; $\mathrm{O}$, molybdate added at zero time and when arrowed. Incubation temperature $30^{\circ} \mathrm{C}$.

was obtained with pure cultures of methanogenic bacteria. Both acetate-utilizing and $\mathrm{H}_{2} / \mathrm{CO}_{2}$-utilizing methanogens were inhibited by the addition of molybdate $\left(20 \mathrm{mmol}^{-1}\right)$ to the culture medium at zero time, although acetate utilizers were unaffected if the inhibitor was added after the cultures had started to produce $\mathrm{CH}_{4}$ actively (Fig. 4). These results were similar, in some respects, to those obtained with sediment slurries, where the effect of molybdate was more marked and persistent if added at zero time. One possible explanation might be that a molybdo-sulphide complex was formed in both the sulphide-rich sediments and the sulphide-containing medium. Both sediments and medium turned a yellow-orange colour after addition of the molybdate. Similar coloration of a medium was reported by Wolin \& Miller (1980) who also demonstrated that the complex could prevent the formation of hydrogenase in Ruminococcus albus, although preformed enzyme was not itself inhibited. The involvement of hydrogenases in methanogenesis, and in the activity of $\mathrm{H}_{2}$-utilizing acetogens, suggests that further studies are required on the effect of concentration on the specificity of molybdate as an inhibitor of sulphate reducers in freshwater sediments such as these. This 
Table 3. Effect of sulphate and molybdate on methanogenesis and $\mathrm{CO}_{2}$ production in small sediment cores

Cores were incubated at $10^{\circ} \mathrm{C}$ for $24 \mathrm{~h}$. Standard deviations are shown in parentheses.

\begin{tabular}{|c|c|c|c|c|c|c|}
\hline \multirow[b]{3}{*}{ Sediment depth $(\mathrm{cm}) \ldots$} & \multicolumn{4}{|c|}{ Rate of methanogenesis [nmol (g dry wt) $)^{-1} \mathrm{~d}^{-1} \mid$} & \multicolumn{2}{|c|}{$\begin{array}{c}\text { Rate of } \mathrm{CO}_{2} \\
\text { production } \mid \mathrm{nmol} \\
\text { (g dry wt })^{-1} \mathrm{~d}^{-1} \mid\end{array}$} \\
\hline & \multicolumn{2}{|c|}{ From acetate } & \multicolumn{2}{|c|}{ From $\mathrm{H}_{2} / \mathrm{CO}_{2}$} & \multicolumn{2}{|c|}{ From acetate } \\
\hline & $0-1$ & $1-2$ & $0-1$ & $1-2$ & $0-1$ & $1-2$ \\
\hline $\begin{array}{l}\text { Conditions } \\
\text { Control } \\
+\mathrm{K}_{2} \mathrm{SO}_{4}\left(0 \cdot 5 \mathrm{mmol} \mathrm{l}^{-1}\right) \\
+\mathrm{Na}_{2} \mathrm{MoO}_{4}\left(20 \mathrm{mmol}^{-1}\right)\end{array}$ & $\begin{array}{c}166(18) \\
128(14) \\
66(4)\end{array}$ & $\begin{array}{c}162(3 \cdot 6) \\
184(0 \cdot 4) \\
68(20)\end{array}$ & $\begin{array}{l}516(158) \\
188(26) \\
364(58)\end{array}$ & $\begin{array}{l}748(236) \\
123(18) \\
364(55)\end{array}$ & $\begin{array}{l}34(2 \cdot 1) \\
116(23) \\
40(29)\end{array}$ & $\begin{array}{l}19(5 \cdot 3) \\
37(23) \\
24(12)\end{array}$ \\
\hline $\begin{array}{l}\text { Proportion of } \mathrm{CH}_{4} \text { produced (\%) } \\
\text { Inhibition by } \mathrm{K}_{2} \mathrm{SO}_{4}(\%) \\
\text { Inhibition by } \mathrm{Na}_{2} \mathrm{MoO}_{4}(\%)\end{array}$ & $\begin{array}{l}24 \\
23 \\
60\end{array}$ & $\begin{array}{r}18 \\
0 \\
42\end{array}$ & $\begin{array}{l}76 \\
64 \\
29\end{array}$ & $\begin{array}{l}82 \\
84 \\
51\end{array}$ & & \\
\hline
\end{tabular}

does not imply that the inhibitor cannot be used satisfactorily to interpret events in $\mathrm{SO}_{4}^{2-}$-dominated marine systems.

Hydrogen-utilizing processes such as methanogenesis are extremely dependent on the partial pressure of $\mathrm{H}_{2}$, and it would be very difficult to maintain natural concentrations of the gas when sediment slurries were incubated for short periods in serum bottles. Practical solutions to this problem might include the following: (1) short-term radiotracer experiments in atmospheres which contain excess $\mathrm{H}_{2}$, thus ensuring maximum velocity of methanogenesis but likely to overestimate the role of the $\mathrm{H}_{2} / \mathrm{CO}_{2}$ pathway if rates are based solely on the natural $\mathrm{CO}_{2}$ concentration (likewise the relative importance of the pathway will be underestimated if the partial pressure of $\mathrm{H}_{2}$ in solution is reduced by incubation under an atmosphere of $\mathrm{N}_{2}$ ); (2) long-term experiments with slurries, in which the natural concentration of $\mathrm{H}_{2}$ is re-established by the microflora and in which measurements are made over the linear part of the methane production curve; (3) short-term experiments with radiotracers using systems in which disturbance of the natural concentrations of all substrates is kept to a minimum. In an attempt to determine the relative importance of the methane precursors and to check the effect of inhibitors under natural conditions we adopted the last of the three solutions. Known concentrations of $\mathrm{H}^{14} \mathrm{CO}_{3}^{-},{ }^{14} \mathrm{CH}_{3} \mathrm{COOH}, \mathrm{K}_{2} \mathrm{SO}_{4}$ and $\mathrm{Na}_{2} \mathrm{MoO}_{4}$ were injected into small sealed cores of sediment with no overlying headspace, and rates of methanogenesis were calculated in a manner analogous to that used by Jørgensen (1978) for determining rates of $\mathrm{SO}_{4}^{2-}$ reduction with ${ }^{35} \mathrm{SO}_{4}^{2-}$. The results showed that more than $75 \%$ of the $\mathrm{CH}_{4}$ generated in Blelham Tarn sediments in late summer was derived from $\mathrm{CO}_{2}$ (Table 3). The generation of $\mathrm{CH}_{4}$ from both $\mathrm{CO}_{2}$ and $\mathrm{CH}_{3} \mathrm{COOH}$ was again inhibited by sulphate and molybdate, the former diverting acetate metabolism to $\mathrm{CO}_{2}$ by stimulating the activity of sulphate-reducing bacteria. Conversion of $\mathrm{CH}_{3} \mathrm{COOH}$ to $\mathrm{CO}_{2}$ was not affected significantly by the addition of molybdate. The results are in agreement with other recent findings (Zaiss, 1981) which illustrate the importance of the $\mathrm{H}_{2} / \mathrm{CO}_{2}$ pathway in certain freshwater environments. Whilst it is accepted that the above is an indirect method of calculating the relative importance of the two methanogenic pathways, we are relatively confident that the results are realistic, since the total amount of $\mathrm{CH}_{4}$ generated on an area basis in the small cores was in reasonable agreement with three other, independent measures of methanogenesis. The rate in the small cores was equivalent to a production of $850 \mu \mathrm{mol}$ $\mathrm{CH}_{4} \mathrm{~m}^{-2} \mathrm{~d}^{-1}$, which compared with results of 235 to $1245 \mu \mathrm{mol} \mathrm{m} \mathrm{m}^{-2} \mathrm{~d}^{-1}$ (based on $\mathrm{CH}_{4}$ accumulation in the hypolimnion over 3 years, Jones \& Simon, 1981), $650 \mu \mathrm{mol} \mathrm{m} \mathrm{m}^{-2} \mathrm{~d}^{-1}$ (field rates in this study derived by extrapolation from $0.5 \mathrm{~m}$ and $0.25 \mathrm{~m}$ above, to the sediment surface) and $1090 \mu \mathrm{mol} \mathrm{m} \mathrm{m}^{-2} \mathrm{~d}^{-1}$ (measured accumulation of $\mathrm{CH}_{4}$ above sediment in 
a sealed Jenkin core). These calculated rates confirm earlier observations (Jones \& Simon, 1980) that the amount of carbon turned over by methanogenesis in Blelham Tarn is significantly less than in many North American lakes (Fallon et al., 1980). A similar treatment of the $\mathrm{SO}_{4}^{2-}$ reduction rates obtained by Jones \& Simon (1981) from experiments with small cores showed that, in the presence of sufficient electron acceptor, sulphate reducers could produce up to $3.25 \mathrm{mmol} \mathrm{CO}_{2} \mathrm{~m}^{-2} \mathrm{~d}^{-1}$. Seasonal means were, however, much lower, as the profundal sediments rapidly became limited in available $\mathrm{SO}_{4}^{2-}$ (Jones, 1982).

We wish to thank Mrs S. Whitehead for excellent technical assistance, Dr D. B. Nedwell for valuable discussions, and Mrs D. Fishwick and Miss E. M. Evans who typed the script. This research was financed by the Natural Environment Research Council.

\section{REFERENCES}

Abdollahi, H. \& Nedwell, D. B. (1979). Seasonal temperature as a factor influencing bacterial sulfate reduction in a saltmarsh sediment. Microbial Ecology 5, 73-79.

Abram, J. N. \& Nedwell, D. B. (1978). Inhibition of methanogenesis by sulphate reducing bacteria competing for transferred hydrogen. Archives of Micro biology 117, 89-92.

Boone, D. R. \& Bryant, M. P. (1980). Propionatedegrading bacterium, Syntrophobacter wolinii. sp. nov. gen. nov., from methanogenic ecosystems. Applied and Environmental Microbiology 40, 626632.

Braun, M., Schoberth, S. \& Gottschalk, G. (1979). Enumeration of bacteria forming acetate from $\mathrm{H}_{2}$ and $\mathrm{CO}_{2}$ in anaerobic habitats. Archives of Microbiology 120, 201-204.

Bryant, M. P., Campbell, L. L., Reddy, C. A. \& Crabill, M. R. (1977). Growth of Desulfovibrio in lactate or ethanol media low in sulfate in association with $\mathrm{H}_{2}$-utilizing methanogenic bacteria. Applied and Environmental Microbiology 33, 1162-1169.

CAPPENBERG, T. E. $(1974 a)$. Interrelations between sulfate-reducing and methane-producing bacteria in bottom deposits of a fresh-water lake. I. Field observations. Antonie van Leeuwenhoek 40, 285295.

CAPpenberG, T. E. $(1974 b)$. Interrelations between sulfate-reducing and methane-producing bacteria in bottom deposits of a fresh-water lake. II. Inhibition experiments. Antonie van Leeuwenhoek 40, 297306.

CappenberG, T. E. \& Prins, R. A. (1974). Interrelations between sulfate-reducing and methaneproducing bacteria in bottom deposits of a freshwater lake. III. Experiments with ${ }^{14} \mathrm{C}$-labelled substrates. Antonie van Leeuwenhoek 40, 457-469.

Cunningham, C. R. \& Davison, W. (1980). An optoelectronic sediment detector and its use in the chemical micro-profiling of lakes. Freshwater Biology 10, 413-418.

Fallon, R. D., HARrits, S., Hanson, R. S. \& Brock, T. D. (1980). The role of methane in internal carbon cycling in Lake Mendota during summer stratification. Limnology and Oceanography 25, 357-360.

FenChel, T. \& BlaCkbuRN, T. H. (1979). Bacteria and Mineral Cycling. London: Academic Press.
Hargrave, B. T. (1969). Epibenthic algal production and community respiration of Marion Lake. Journal of the Fisheries Research Board of Canada 26, 2003-2026.

Hoban, D. J. \& van den Berg, L. (1979). Effect of iron on conversion of acetic acid to methane during methanogenic fermentations. Journal of Applied Bacteriology 47, 153-159.

Jones, J. G. (1976). The microbiology and decomposition of seston in open water and experimental enclosures in a productive lake. Journal of Ecology 64, 241-278.

JONES. J. G. (1982). Activities of aerobic and anaerobic bacteria in lake sediments and their effects on the water column. In Microbiology of Sediments. Edited by C. M. Brown, M. J. Latham \& D. B. Nedwell. London: Academic Press (in the Press).

Jones, J. G. \& Simon, B. M. (1980). Decomposition processes in the profundal region of Blelham Tarn and the Lund tubes. Journal of Ecology 68, 493-512.

Jones, J. G. \& Simon, B. M. (1981). Differences in microbial decomposition processes in profundal and littoral lake sediments, with particular reference to the nitrogen cycle. Journal of General Microbiology 123, 297-312.

Jones, J. G., Downes, M. T. \& TAlling, I. B. (1980). The effect of sewage effluent on denitrification in Grasmere (England Lake District). Freshwater Biology 10, 341-359.

JøRGENSEN, B. B. (1978). A comparison of methods for the quantification of bacterial sulfate reduction in coastal marine sediments. I. Measurement with radiotracer techniques. Geomicrobiology Journal 1, $11-27$.

Jørgensen, B. B. (1980). Mineralization and the bacterial cycling of carbon, nitrogen and sulphur in marine sediments. In Contemporary Microbial Ecology, pp. 239-251. Edited by D. C. Ellwood, J. N. Hedger, M. J. Latham, J. M. Lynch and J. H. Slater. London: Academic Press.

LATHAM, M. J. \& Wolin, M. J. (1978). Use of a serum bottle technique to study interactions between strict anaerobes in mixed culture. In Techniques for the Study of Mixed Populations, pp. 113-124. Edited by D. W. Lovelock \& R. Davies. London: Academic Press.

Mcinerney, M. J., Bryant, M. P. \& Pfennig, N. 
(1979). Anaerobic bacterium that degrades fatty acids in syntrophic association with methanogens. Archives of Microbiology 122, 129-135.

Molongoski, J. J. \& KLUG, M. J. (1980). Anaerobic metabolism of particulate organic matter in the sediments of a hypereutrophic lake. Freshwater Biology 10, 507--518.

Morris, J. G. (1974). A Biologist's Physical Chemistry, 2nd edn. London: Edward Arnold.

Oremland, R. S. \& TAYlOR, B. F. (1978). Sulfate reduction and methanogenesis in marine sediments. Geochimica et cosmochimica acta 42, 209-214.

Patel, G. B., Khan, A. W. \& Roth, L. A. (1978). Optimum levels of sulphate and iron for the cultivation of pure cultures of methanogens in synthetic media. Journal of Applied Bacteriology 45. 347-356.

PECK, H. D. (1959). The ATP-dependent reduction of sulfate with hydrogen in extracts of Desulfovibrio desulfuricans. Proceedings of the National Academy of Sciences of the United States of America 45 , 701-708.

Postgate, J. R. (1963). Versatile medium for the enumeration of sulfate-reducing bacteria. Applied Microbiology 11, 265-267.

Rees, T. D., Gyllenspetz, A. B. \& Docherty, A. C. (1971). The determination of trace amounts of sulphide in condensed steam with $N, N$-diethyl-pphenylenediamine. Analyst 96, 201-208.

RUdD, J. W. M. \& HAMILTON, R. D. (1978). Methane cycling in a eutrophic shield lake and its effects on whole lake metabolism. Limnology and Oceanography 23, 337-348.

Schonheit, P., Moll, J. \& Thauer, R. K. (1979). Nickel, cobalt and molybdenum requirement for growth of Methanobacterium thermoautotrophicum. Archives of Microbiology 123, 105-107.

Strayer, R. F. \& Tiedje, J. M. (1978). Kinetic parameters of the conversion of methane precursors to methane in a hypereutrophic lake sediment. Applied and Environmental Microbiology 36, 330340.

TaBATABAI, M. A. (1974). Determination of sulfate in water samples. Sulfur Institute Journal 10, 11-12.
Wetzel, R. G., Rich, P. R., Miller, M. C. \& Allen, H. L. (1972). Metabolism of dissolved and particulate detrital carbon in a temperate hard-water lake. Memorie dell'Istituto italiano di idrobiologia Dott. Marco de Marchi 29 (Supplement), 185-243.

Winfrey, M. R., Nelson, D. R., Klevickis, S. C. \& ZeIKus, J. G. (1977). Association of hydrogen metabolism with methanogenesis in Lake Mendota sediments. Applied and Environmental Microbiology 33, 312-318.

Winfrey, M. R. \& Zeikus, J. G. (1977). Effects of sulphate on carbon and electron flow during microbial methanogenesis in freshwater sediments. Applied and Environmental Microbiology 33, 275281.

Winfrey, M. R. \& Zeikus, J. G. (1979). Anaerobic metabolism of immediate methane precursors in Lake Mendota. Applied and Environmental Microbiology 37, 244-253.

Wolin, M. J. \& Miller, T. J. (1980). Molybdate and sulfide inhibit $\mathrm{H}_{2}$ and increase formate production from glucose by Ruminococcus albus. Archives of Microbiology 124, 137-142.

ZaIss, U. (1981). Seasonal studies of methanogenesis and desulfurication in sediments of the River Saar. Zentralblatt für Bakteriologie, Parasitenkunde, Infektionskrankheiten und Hygiene (Abteilung $I$ ) (in the Press).

Zaiss, U. \& Kaltwasser, H. (1979). Hydrogenase activity and methanogenesis in anaerobic sewage sludge, in rumen fluid, and in freshwater sediments. European Journal of Applied Microbiology and Biotechnology 8, 217-227.

ZehNder, A. J. B., HuSER, B. \& Brock, T. D. (1979). Measuring radioactive methane with the liquid scintillation counter. Applied and Environmental Microbiology 37, 897-899.

Zeikus, J. G. (1977). The biology of methanogenic bacteria. Bacteriological Reviews 41, 514-541.

Zeikus, J. G. \& Winfrey, M. R. (1976). Temperature limitation of methanogenesis in aquatic sediments. Applied and Environmental Microbiology 31, 99107. 